\title{
Correction: New score for assessing bleeding risk in patients with atrial fibrillation treated with NOACs
}

Rutherford OW, Jonasson C, Ghanima W, et al. New score for assessing bleeding risk in patients with atrial fibrillation treated with NOACs. Open Heart 2018;5: e000931.doi:10. 1136/openhrt-2018-000931.

In Table 4, row 4, column 'Score', data should read '2 for age $>75$ ' and not 'for age $>75$.

Open access This is an open access article distributed in accordance with the Creative Commons Attribution Non Commercial (CC BY-NC 4.0) license, which permits others to distribute, remix, adapt, build upon this work non-commercially, and license their derivative works on different terms, provided the original work is properly cited, appropriate credit is given, any changes made indicated, and the use is non-commercial. See: http://creativecommons.org/licenses/by-nc/4.0/.

C Author(s) (or their employer(s)) 2020. Re-use permitted under CC BY-NC. No commercial re-use. See rights and permissions. Published by BMJ.

Open Heart 2020;7:e000931corr1. doi:10.1136/openhrt-2018-000931corr1

(A) Check for updates 